\title{
Ortaokul Beşinci Sınıf Matematik Dersi Bölme İşlemi Konusunda Plickers Uygulamasının Matematik Kaygısına ve Matematik Başarısına Etkisi
}

\author{
DOI: 10.26466/opus.578149
}

\author{
* \\ Murat Tuncer*- Manolya Şimşek** \\ * Doç.Dr., Fırat Üniversitesi Eğitim Fakültesi, Elazı ğ/Türkiye \\ E-Posta: mtuncer@firat.edu.tr \\ ORCID: 0000-0001-9136-6355 \\ ** Öğretmen, Milli Eğitim Bakanlığı, Diyarbakır / Türkiye \\ E-Posta: manolyaaydin@gmail.com \\ ORCID: 0000-0003-2747-3310
}

Öz

Bu araştırmanın amacı Plickers uygulamasının ortaokul beşinci sinıf matematik öğrencilerinin matematik kaygısına ve matematik dersi başarlarına etkisini incelemektir. Araştırmada nicel araştırma yöntemlerinden eşitlenmemiş ön test - son test kontrol gruplu yarı deneysel desenden yararlanılmıştır. Araştırmanın çalışma grubunu 2017-2018 Ĕ̆itim öğretim yılında Diyarbakır'da bir ortaokulun üç farklı beşinci sınıf şubesinde öğrenim gören 72 öğrenci oluşturmaktadır. Araştırma grubu, bir deney iki kontrol grubu olacak şekilde yapilandirlmıştır ve deney grubunda 3 haftalık Plickers uygulaması yapılmıştır. Veri toplama aracı olarak, Bindak'ın (2005) geliştirdiği matematik kaygı ölçeği ve araştırmacı tarafından hazırlanan, geçerlik ve güvenirlik çalışması yapılan matematik başarı testi kullanılmıştır. Verilerin analizinde Kolmogorov Smirnov, Kruskal Wallis H ve karma desenli ANOVA testlerinden yararlanılmıştır. Araştırma sonucunda Plickers uygulamasının matematik dersi bölme konusunda akademik başarıyı olumlu yönde etkilediği belirlenmiştir. Plickers uygulaması sinıf akademik başarıların kademeli olarak artırmaktadır. Ancak Plickers uygulamasının matematik kaygısın etkilediğine yönelik bir bulguya rastlanmamıştır. Test öncesi ve sonrasında deney grubunun düşük düzeyde bir kaygı yaşadığı belirlenmiştir.

Anahtar Kelimeler: Matematik başarısı, Matematik kaygısı, Plickers uygulaması, Teknoloji destekli biçimlendirici de ğerlendirme 


\title{
The Effect of Plickers Application on Anxiety and Achievement in Secondary School 5th Mathematics Lesson About Division
}

\begin{abstract}
Classroom teaching, considering the population they address, is a field of profession that constitutes a role model for students and contributes to the habits they adopt. In this sense, the nutritional habits of classroom teachers also constitute a significant point. This is because, when teachers have a correct and regular nutritional habit, they can instill this habit in students. In this study, it was aimed to investigate the nutritional habits of classroom teachers. The nutritional habit survey, prepared in line with this aim, was conducted with classroom teachers. In the data analysis, SPSS package software was used and percentage, frequency, standard deviation and arithmetic mean tests were conducted. According to the results of the study, a majority of the teachers stated that they did not receive nutritional training, did not have smoking or drinking habits in addition to not doing any physical activity. Approximately half of the participating teachers in the study reported that they do not have a habit of having breakfast and they skipped meals as well as reporting that the most skipped meal was the lunch. The teachers, as the reason for skipping meals, stated that they skipped meals because they could not get the chance. A majority of the participating teachers in the study also stated that they consumed less than two liters of waters in a day and they consumed less than five or six cups of tea or coffee in a day. As a result of the study, it was observed that the nutritional habits of teachers and the level of their knowledge were insufficient.
\end{abstract}

Keywords: Mathematics achievement, Mathematics anxiety, Plickers applications, Technology enhanced formative evaluations 


\section{Giriş}

İlkokuldan başlayarak eğitimin her kademesinde temel derslerden biri olarak görülen matematik, ulusal düzeyde yapılan tüm sınavlarda ayırt edici ve belirleyici bir özelliğe sahiptir. Ancak gerek ulusal (YGS, TEOG vb.), gerekse uluslararası düzeyde (PISA, TIMSS) yapılan sınavlarda ülkemizin matematik ortalamalarının oldukça düşük düzeylerde olduğu (Berkant ve Gençoğlu, 2015) görülmektedir.

Türkiye'de ilkokul düzeyinden üniversiteye kadar matematiğin bir ders olarak verilmesi ve ders saati bakımından diğer derslere oranla daha fazla olması dikkate alındığında ulusal düzeyde düşük matematik başarısının görülmesi ve bunun devam etmesi ciddi bir problem olarak karşımıza çıkmaktadır. Kariyer basamaklarını tırmanmada önemli bir yer tutan bu disiplinin öğrencilerin çoğu tarafından sevilmediği (Aydın, 2003), zor ve sıkıcı bir ders olduğu (Toluk Uçar v.d., 2010) belirtilmektedir.

Yılmaz ve Bindak'a (2016) göre matematik başarısının düşük olması araştırmacıları öğrenen başarısını etkileyen diğer faktörleri araştırmaya yöneltmiştir. Matematik ders başarısının düşüklüğüne yönelik olarak alan yazında çeşitli araştırmaların olduğu görülmektedir. Genel olarak öğrenen başarısızlıklarının nedenleri; öğretmen nitelikleri, öğretim yaklaşımları, yetersiz çalışma, öğrenme ortamı ile ilgili sorunlar, konu alanı ve s1navlar ile ilgili sorunlar, psikolojik sorunlar, aile ilişkilerindeki sorunlar, öğrenim görülen bölüm ile ilgili gelecek kaygısı ve zaman yönetimi şeklinde (Aysan, Tanriöğen ve Tanrı̈ğen, 1996) ifade edilmektedir. Turgut (1986) ise öğrencilerdeki başarısızlık nedenlerini, öğrencilerden kaynaklanan durumlar, çevreden kaynaklanan durumlar, programdan kaynaklanan durumlar ve öğretmenden kaynaklanan durumlar olmak üzere dört grupta toplamaktadır (Tekin, 2010). Suan (2014) ise matematik başarı düşüklüğ̈̈ konusunda oldukça geniş bir nedensellik bağlamı kurmuş, öncelikli etkenler olarak öğretim strateji ve teknikleri, sinıf yönetimi ve iletişim becerilerini, ikinci olarak çalışma alışkanlığı, zaman yönetimi, matematiğe karşı tutum ve davranışları, üçüncü olarak ailelerin matematiğe verdiği değer, sınıf özellikleri ve akran gruplarını göstermiştir. Davranışsal sınıflama açısından bakıldı̆̆ında ise matematik başarısını bilişsel (Singh, 
Granville ve Dika, 2002) ve duyuşsal (tutum, inançlar, değerler ve öz yeterlik gibi) etmenlerin de etkileyebildiği (Lebens, Graff ve Mayer, 2011; Grootenboer ve Marshman, 2015) bilinmektedir.

Başarıyı etkileyen faktörlerden biri olarak görülen öğrenenlerin bilişsel ve duyuşsal özellikleri, öğrenme düzeyleri arasında farklılıkları oluşturmaktadır. Bloom'un (1979) geliştirdiği Tam Öğrenme Modeli'nde bireylerin öğrenmeleri arasındaki farklılıkların \% 25'inin kaynağı duyuşsal faktörlerden oluştuğu belirtilmektedir (İlhan ve Öner Sünkür, 2012). Öğrenmede oldukça yüksek bir etkiye sahip olan duyuşsal durumlardan; matematik kaygısı öğrencilerin bu derse yönelik olumsuz tutum geliştirmelerine sebebiyet veren duyuşsal özelliklerden biridir (Tooke ve Leonard, 1998; Akt: Bekdemir, 2007). Matematik başarısını etkileyen faktörlerden biri olarak matematik kaygısı ile ilgili alanyazında birçok tanım bulunmaktadır. Matematik kaygısını Richardson ve Suinn (1972) matematik problemlerinin çözümünde bir engel olarak görmektedir (Akt: Arslan, 2008). Miller ve Mitchell'e göre (1994) ise, matematik kaygısı öğrencilerin matematik performanslarını olumsuz etkileyen "mantık dışı korku" durumudur (Akt: Yetgin, 2017). Bir başka tanımda Ashcraft ve Faust (1994) matematik kaygısını problem çözümünde ortaya çıkan çaresizlik ve gerilim duygusu olarak tanımlamıştır (Akt: Dede ve Dursun, 2008).

Başarı ve öğrenmeler üzerinde önemli etkileri olan matematik kaygısının nedenleri yurt içi ve yurt dışında birçok araştırmacının çalışma alanı olmuştur. Matematik kaygısının sebepleri; matematik öğretiminden kaynaklanan genel ve yöntemsel unsurlar ile öğrenci özellikleri olmak üzere üç başlıkta sınıflanabilir (Keçeci, 2011). Matematik kaygısının nedenlerini öğrencilerin algılarına göre araştıran Alkan (2011), öğrencilerin matematik dersine ait kaygılarının; öğretmenlerden, öğrencilerin kendilerinden, ailelerinden ve arkadaşlarından kaynaklandığı sonucuna ulaşmıştır. Trujillo ve Hadfield (1999) matematik kaygısının nedenleri olarak öğretim esnasında yaşanan olumsuz deneyimleri ve zamanla oluşan önyargıları, öğrenene yönelik aile baskısını ve öğretmenlerin pedagojik ve alan bilgisi bakımından yetersizliklerini, öğrencinin öğrenme stili ile öğretim yöntemlerinin örtüşmemesini, öğrenci tutumları, motivasyon eksikliği, kişinin öz değer algısının düşük olmasını sıralamaktadır (Akt: Deniz ve Üldaş, 2008). Matematik dersinde sınıf içindeki başarısızlık anında, diğer öğrencilerin gülme, alay etme (Alkan, 2011) vb. tepkileri, matematik dersinin 
sevilmesi ve öğretmen memnuniyeti (Peker ve Şentürk, 2012), öğretmen davranışları, bazı konuların güçlük derecesi, cinsiyete yönelik olumsuz algılar, eğitici ilgisizliği, öğretmenlerin yüksek beklentileri, iletişim, öğretimin niteliği (Jackson ve Leffingwell, 1999; Akt: Bekdemir, 2007) matematik kaygısını etkileyen faktörler arasındadır. Öğrencilerin hata yapma korkusu (Zakaria ve Nordin, 2008; Akt: Keçeci, 2011), öğretmenin olumsuz tutum ve uygulamaları ve öğretmenlerin keskin, sert, aşağılayıcı ve kaba davranışları (Baydar ve Bulut, 2002) gibi ekenlerin öğrencilerde matematik kaygısını oluşturduğu görülmüştür. Ayrıca öğrencinin sınıf ortamında kendini rahat ve güvende hissetmemesi ve arkadaşları ile iyi bir iletişim kurmaması (Alkan, 2011) matematik kaygısını oluşturacak durumlardır. Matematiğe yönelik istenmeyen bir kaygı düzeyinde olan aileler çocuklarına verdikleri açık ve örtük mesajlar ile onlarda bu derse karşı olumsuz önyargıların oluşmasına neden olmaktadırlar (Levine ve Beilock 2015; Akt: Aydın ve Keskin, 2017). Bunların dişında sınıf içinde akademik başarısı oldukça yüksek öğrencilerin davranışları, başarısı düşük olan öğrencilerde yetersizlik duygusunun oluşmasına neden olabilmektedir. Toplumumuzda matematik oldukça önemli bir ders olarak görüldüğü için ailelerin çocuklarına matematik başarısı beklentisi içinde olduklarını hissettirmeleri, öğrencilere sorumluluk yüklemekte ve matematik kaygısının oluşmasına neden olabilmektedir.

Tüm bu faktörlerin dişında matematik öğretiminde konuların zorluk düzeyi kaygının oluşmasına neden olabilmektedir. Doğal sayılarla dört işlemi yapabilmede öğrencilerin en çok güçlük yaşadıkları işlemin bölme işlemi olduğu bilinmektedir (Albayrak ve Şimşek, 2017). Bölme işleminin zorluğunu Ayvaz (2010) gerek anlamının gerekse işlem tekniğinin kavranması bakımından dört işlem içinde öğrencilere en zor görüneni olarak ifade etmiştir. Bölme işleminin zorluğunu, Nures ve Bryant (2008: 221), okullarda toplama ve çıkarma işleminin çarpma ve bölme işleminden önce verilmesini yine insanların çarpma ve bölme işlemini daha zor ve karmaşık görmelerine bağlamaktadır (Akt: Varol ve Kubanç, 2015). Bu araştırmayı sınırlandıran ortaokul 5. sınıf matematik dersi bölme konusunun, toplama, çıkarma ve çarpma gibi önkoşul işlemleri içermesinden dolayı öğrencilerin performansını etkileyebileceği düşünülmektedir. Alanyazında, bölme işleminde önkoşul öğrenmelerin zorunluluğunu açıklayan çeşitli çalışmalar yer almaktadır. Sidekli, Gökbulut ve Sayar (2013) 
dört işlem becerisinin geliştirilmesiyle ilgili yaptıkları çalışmada, toplama, çıkarma ve çarpma işlemlerinde güçlük yaşayan öğrencilerin bölme işlemlerinde güçlük yaşadıkları gözlemlenmiş, toplama ve çıkarma işlemlerinde yaşanan sıkıntılar düzeltildiğinde öğrencilerin bölme işlemindeki başarısının da \% 60 ile \% 80 düzeyinde arttığını ifade etmişlerdir. Ön şart ilişkilerinin en güçlü olduğu alan olan matematikte (Yenilmez ve Kakmac1, 2008), önkoşul öğrenmelerin sağlanmasıyla bölme işleminde başarının arttığ1 görülmüştür. Başka bir deyişle, bölme işlemine geçmeden önce öğrenenlerin önceki öğrenmeleri yani hazırbulunuşluk düzeyleri, öğretim için önemli bir faktördür.

Öğrenenlerin öğretim için hazırbulunuşluk düzeyleri de (Bekdemir, 2009) kaygıyı oluşturabilecek nedenlerden biridir. Ön koşul öğrenmelerin sıklıkla yer aldığı bir disiplin olan matematik, öğrenme eksikliklerinin ve kavram yanılgılarının erken tespit edilemediği durumlarda, öğrenci için giderek karmaşıklaşan, anlaşılmayan ve zorlaşan bir derse dönüşmektedir (Altun, 2001). Öğrencinin matematiği başaramayacağını düşünmesi hatta onunla ilgili konularla uğraşmak istememesinin sonucunda, matematik dersine karşı kaygı duyması ve dersi sevmemesi beklenebilir (Yenilmez ve Özbey, 2006). Birçok faktörden dolayı ortaya çıkabilen matematik kaygısının giderilmesinde, öğretmenlere de görevler düşmektedir. Öğretmenler, demokratik ve cesaretlendirici bir sinıf ortamı oluşturmalı, öğrencilerin öğrenme süreçlerinde yaşadıkları sıkıntılara çözümler bulmalıdırlar. Öğretmenler öğretim sürecinin etkililiği ve öğrenmeler hakkında bilgiler sunduğu için ölçme değerlendirme süreçlerine önem vermelidir.

Diğer derslerde olduğu gibi matematik öğretiminin önemli bir basamağı olan değerlendirme, öğretimde sadece belirli bir zamana değil öğretim sürecinin tümü ile kaynaştırıldığında derin ve nitelikli öğrenmeler sağlar (National Council of Teachers of Mathematics [NCTM], 2000).Yap1landırmacı öğrenme yaklaşımında ölçme ve değerlendirme, öğretim sürecinin bir parçasıdır ve sadece öğrenmenin başında ve sonunda değil, öğrenme süreci boyunca her önemli noktada yer alır (Gelbal ve Kelecioğlu, 2007). Bu şekilde yapılan değerlendirmede, değerlendirme yapılsa da öğrenme devam eder ve bu nedenle sadece ürün değil sürecin değerlendirilmesi daha önem taşır (Yazar ve Şimşek, 2017). Biçimlendirici değerlendirmede önemli olan öğrenciye sadece not vermek değil, öğrencilerin çalışma 
ve performanslarından elde edilen bilgileri kullanılarak yeteneklerini şekillendirmek ve gelişimlerinin farkına varmalarını sağlamaktır (Tunstall ve Gipps, 1996; Akt: Köğce, 2012). Heritage'e (2008) göre de biçimlendirici değerlendirme, şu anki öğrenme durumu ile istenilen hedefler arasındaki boşluğu kapatmak için öğretmen ve öğrencilere geri bildirim sağlayarak tüm öğrenme ve öğretme süresince sürekli olarak yer almalıdır (Akt: Ozan, 2017). Değerlendirme türleri arasında, özellikle biçimlendirici değerlendirmenin öğrencinin başarısına olumlu katkı sağladığı, öğrenenin düzeyini ve kalitesini artırdığı bilinmektedir (Harlen ve Qualter, 1991; Gipss,1994a; Akt: Türkdoğan, 2011). Tekin (2010) biçimlendirici değerlendirmenin matematik dersinde başarıya, tutuma ve öğrenilenleri hatırlamaya olumlu etkileri olduğunu belirlemiştir. Bu nedenle matematik öğretiminde biçimlendirici değerlendirmeler, geri bildirimler ve düzeltmeler ciddi bir öneme sahiptir. Öğretim sırasında yapılan biçimlendirici değerlendirme ve öğrencilere sunulan geri bildirimler matematik öğretimi için ön koşul öğrenmelerin gerçekleşmesini sağlayarak öğrenciyi bir sonraki aşamaya hazırlayabilir. Öğrencilerin eksikliklerinin giderilerek sonraki etkinliklere geçilmesi daha etkili bir öğrenme sürecinin oluşmasına imkân tanımaktadır (Atılgan, 2011). Bu nedenlerden dolayı matematik öğretiminde biçimlendirici değerlendirme büyük bir önem arz etmektedir.

Biçimlendirici değerlendirme uygulamalarında teknoloji kullanımına yönelik ilgi giderek artmaktadır (Luckin v.d., 2017). Geçmişte teknoloji genellikle düzey belirleyici değerlendirmelerde kullanılırken, yenilikçi mobil uygulamalar sayesinde günümüzde bu durum öğrenme öğretme sürecini daha etkileşimli hale getirmiştir. Web ve mobil teknolojilerin gelişmesiyle ölçme ve değerlendirmede anında ve ayrıntılı veri analizi sunan, ölçme ve değerlendirme süresini kısaltarak zamandan tasarruf sağlayarak öğretmenlere çeşitli açlardan kolaylık sağlayabilen yazılımlar ortaya çımıştır (Bars, Şimşek ve Zengin, 2017). Öğrenci yanıt sistemi, dinleyici yanıt sistemi gibi adlarla ifade edilebilecek bu sistemlerin yerini günümüzde cep telefonu uygulamaları almıştır. Kahoot, Socrative ve Plickers bunlardan birkaçıdır. Bu uygulamalardan Plickers öğrencilerin mobil bir cihaza ya da uygulamaya gerek duymadığı, yalnızca öğretmenin kendi mobil cihazına ücretsiz bir uygulama yükleyerek ve cihazının kamerasıyla öğrencilerin yanıtlarını aldığı çevrim içi bir ölçme ve değerlendirme sistemidir 
(Şimşek, Bars ve Zengin, 2017). Android ve Apple kullanıcıları için rahatlıkla erişilebilen Plickers uygulaması öğrenciler açısından Plickers kartı denen kağıtlar dışında bir ekipman gerektirmemektedir (Krause, O'neil ve Daunheauer, 2017). Bu yönüyle oldukça ekonomik bir uygulama olarak tanımlanabilir.

21. yüzyılda yeni teknolojilerle birlikte öğrencilerin çeşitli etkinliklerde performanslarının nasıl ilerlediği kolayca değerlendirilebilmekte ve düzeltmeler yapılarak farklı düzeylerdeki öğrencilere yardım edilebilmektedir (Bichsel, 2012). Sınıf içi ölçme ve değerlendirme süreçleri teknoloji destekli biçimlendirici değerlendirmeye hizmet etmektedir. Bu değerlendirmelerde öğrencilerin kayıtları tutulmakta, öğrencilerin öğrenmeleri izlenmekte ve öğrencilerin gelişimi hakkında değerlendirme yapmaya olanak sağlanmaktadır (Luckin v.d., 2017). Nitekim alanyazında teknoloji destekli biçimlendirici değerlendirmelerin öğrencilerin matematik dersine katılımlarını olumlu etkilemesi (Ortiz, 2014) ile ilgili çeşitli araştırmalar yer almaktadır. Bu uygulamalar, öğrenme eksikliklerini belirleme, anında dönüt düzeltme verme ve öğrenci gelişimini izlemede öğretmene kolaylıklar sağlaması nedeniyle matematik dersinde biçimlendirici değerlendirme aracı olarak kullanılabilirler.

Alanyazında Plickers uygulamasının akademik başarı (Chou, 2017; Thomas vd. 2016; Wood, Brown ve Grayson, 2017; MacCargo, 2017) ve matematik kaygısı (Marshall v.d., 2017) üzerinde etkileri olduğu belirtilmiştir. Plickers gibi bir mobil uygulamanın, öğrenci yanıt sistemi olarak biçimlendirici değerlendirmede kullanılmasının matematik öğrenme sürecine bilişsel (başarı) ya da duyuşsal (kaygi) olarak çeşitli etkileri olabilir. Bu tür dijital araçların pedagojik özelliklerinin deneysel olarak incelenmesinin, öğrenmeye etkilerinin anlaşılmasına yardımcı olacağı düşünülmektedir.

Yukarıda bahsedilen önem ve gerekliliklerden yola çıkılarak bu araştırmanın amacı Plickers uygulamasının ortaokul beşinci sınıf matematik dersinde öğrencilerin matematik kaygısına ve matematik dersi başarılarına etkisini incelemektir. Bu amaç doğrultusunda aşağıdaki sorulara yanit aranmiştır:

1. Deney ve kontrol gruplarının öntest ve sontest başarı puanları anlamlı biçimde farklılaşmakta mıdır? 
2. Deney ve kontrol gruplarının matematik dersi bölme konusu başarı puanları anlamlı biçimde farklılaşmakta mıdır?

3. Deney ve kontrol gruplarının ön-test ve son-test matematik kayg1 puanları arasında anlamlı bir fark var midır?

\section{Yöntem}

\section{Araştırma Deseni}

Araştırmada nicel araştırma yöntemlerinden eşitlenmemiş ön test - son test kontrol gruplu yarı deneysel desenden yararlanılmıştır. Araştırmanın deseni Tablo 1'de gösterilmiştir.

Tablo 1. Deneysel işlem süreci

\begin{tabular}{llll}
\hline Gruplar & & Uygulama (3 hafta) & \\
Deney & Ön test & $\begin{array}{l}\text { Normal ders süreci ve } \\
\text { Plickers uygulaması }\end{array}$ & Son test \\
Kontrol 1 & Ön test & Normal ders süreci & Son test \\
Kontrol 2 & Ön test & Normal ders süreci & Son test \\
\hline
\end{tabular}

Ön test ve son testlerde matematik dersi bölme konusu başarı testi ve matematik kaygı ölçeği kullanılmıştır.

\section{Çalışma Grubu}

Çalışma grubu, 2017-2018 eğitim-öğretim yılında Diyarbakır'da bir ortaokulun üç farklı beşinci sinıf şubesinde öğrenim gören 72 öğrenciden oluşmaktadır. Gruplar basit seçkisiz yöntemle belirlenmiştir. Buna göre bir deney ve iki kontrol grubu araştırmanın çalışma grubunu oluşturmaktadır. Araştırmada ön testte yer alıp son testte yer almayan, ölçekleri ya da başarı testlerini eksik ve yanlış yanıtlayan ya da yanıt vermeyen yedi katılımcının verileri analiz dışı bırakılmıştır. 


\section{Deneysel Isşlemler}

Araştırma ortaokul beşinci sınıf matematik derslerinde 3 hafta boyunca yürütülmüştür. $\mathrm{Bu}$ sürenin belirlenmesinde kazanımlar için gerekli görülen öğretim zamanı ve içerik belirleyici olmuştur. Deney ve kontrol gruplarındaki matematik derslerini aynı öğretmen yürütmüştür. Araştırmacı deney ve kontrol gruplarında gözlemci olarak yer almıştır. Deney grubunda, normal ders sürecine ek olarak, kazanımlara ilişkin soruların yer aldığı Plickers uygulaması yaptırılmış, kontrol gruplarına herhangi bir müdahalede bulunulmamıştır. Matematik öğretmeni kontrol gruplarını oluşturan her iki sınıfta da aynı yöntem ve teknikle (Anlatım, Sorucevap ve Tartışma) dersini işlemiş, sadece deney grubunda bazı derslerin sonunda Plickers uygulaması yapmıştır. $\mathrm{Bu}$ araştırmanın konusunu oluşturan içerik öğretim programında "En çok dört basamaklı bir doğal sayıyı, en çok iki basamaklı bir doğal sayıya böler.", "Doğal sayılarla çarpma ve bölme işlemlerinin sonuçlarım tahmin eder."," Doğal sayılarla zihinden çarpma ve bölme işlemlerinde uygun stratejiyi belirler ve kullanır.", "Bölme işlemine ilişkin problem durumlarında kalanı yorumlar." ve "Çarpma ve bölme işlemleri arasındaki ilişkiyi anlayarak işlemlerde verilmeyen ögeleri (çarpan, bölüm veya bölünen) bulur" kazanımları içermektedir.

\section{Plickers Uygulaması}

Cep telefonuna yüklenen plickers bilgisayar ve cep telefonun birlikte kullanıldığı bir uygulamadır. www.plickers.com adresinden sisteme giriş yapan öğretmen, sınıftaki her öğrenciyi sisteme tanımlayarak, her öğrenciye bir numara vermiştir. Öğretmen, üzerinde sistemde tanımlanmış numara bulunan ve her biri farklı olan Plickers kartlarını çıktı almıştır. Bu kartlar beyaz kağıdın üzerinde yer alan siyah bir şekilden oluşmaktadır. Bu siyah şeklin dört tarafında A,B,C,D şıkları yer almaktır. Şekil 1'de örnek plickers kartları yer almaktadır. 

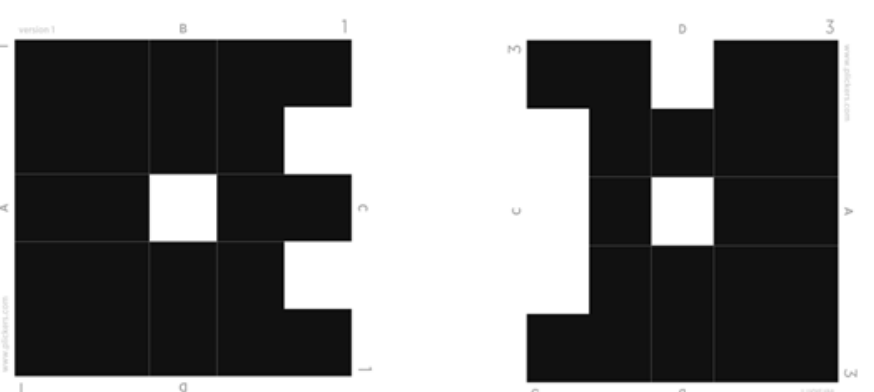

Şekil 1.Örnek Plickers kartları

Öğretmen bilgisayarda plickers kütüphanesine, kazanımlara ilişkin, ders kitabındaki örneklere benzer düzeyde soruları ve bu soruların cevaplarını yüklemiştir. Sorular 4 seçenekten oluşacak şekilde hazırlanmıştır. Yüklenen sorulara ilişkin bir ekran görüntüsü Şekil 2'de görülmektedir.

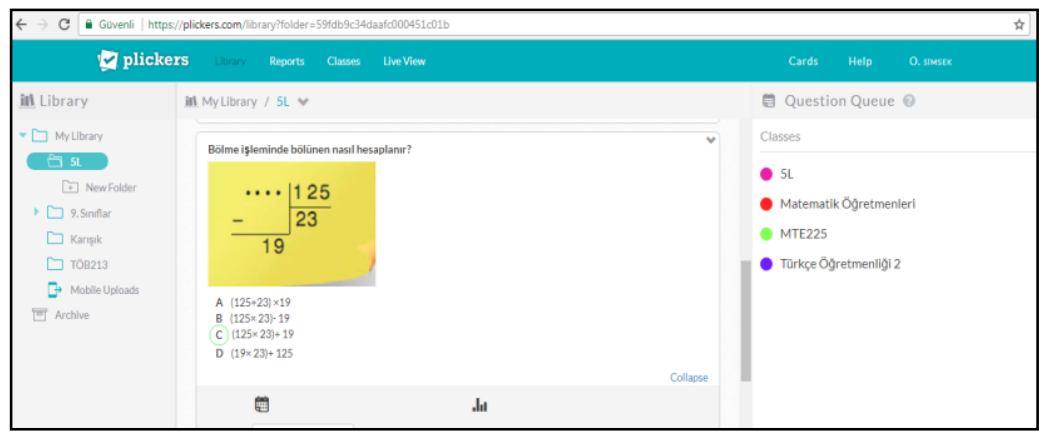

Şekil 2.Plickers kütüphanesine yüklenen soru örneği

Öğretmen, kütüphaneye kaydettiği soruları cep telefonundan seçerek, tahtaya yansıtmıştır. Akıllı tahtaya soru yansıtıldıktan sonra öğrencilere soruyu cevaplamaları için yeterli süre tanınmıştır. Öğrenciler soruları çözdükten sonra, hangi seçeneği yanıtlamışlarsa, ona göre plickers kartlarını seçeneğe göre havaya kaldırmışlardır. Öğretmen cep telefonda plickers uygulaması sırasında kamera butonuna basarak sinıftaki bu kartları tarayarak öğrenci yanıtlarını kaydetmiştir. Şekil 3'te öğrencilerin Plickers kartlarını kullanımına yönelik bir görsel verilmiştir. 


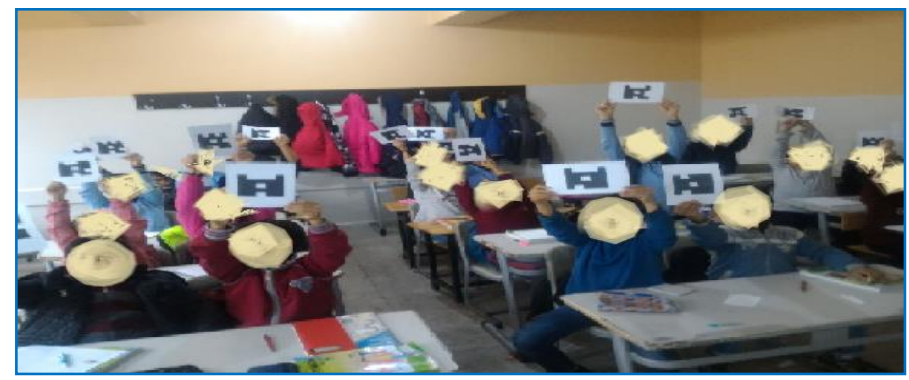

Şekil 3. Öğrencilerin Plickers kartlarıla yanıt vermeleri

Öğretmen tüm sınıfın cevaplarını taradıktan sonra, kendi cep telefonunda sınıfın doğru yanıt yüzdesini ve yanlış yapanları görebilmektedir. Bu duruma yönelik ekran görseli Şekil 4'de verilmiştir.

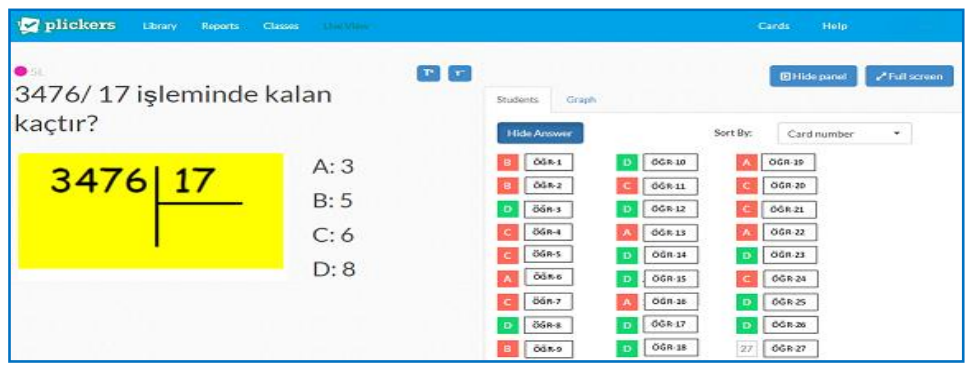

Şekil 4. Öğrencilerin Plickers uygulamasına verdiği yanttlar

Ders sırasında yapılan tüm işlemleri kaydeden Plickers uygulaması, daha sonrasında soruların ve cevapların incelenmesinde kolaylık sağlamaktadır. Şekil 5'te sorulara verilen yanıtların grafiğine ilişkin ekran görseli görülmektedir.

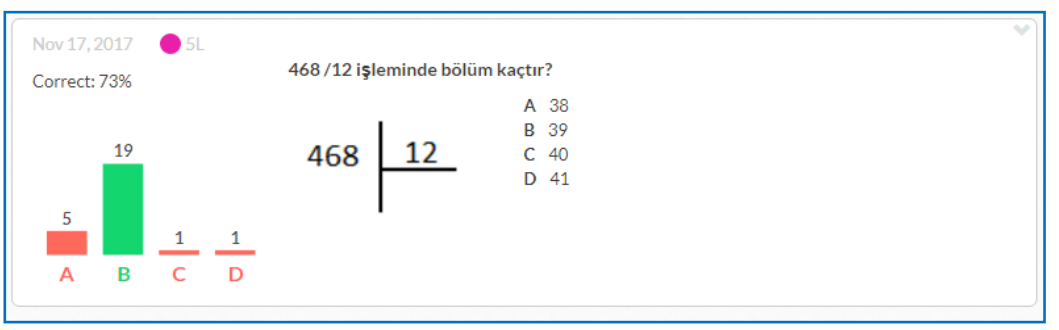

Şekil 5. Verilen yanttların Plickers uygulamasında grafiksel olarak gösterimi 
Şekil 5'teki yantların grafiksel gösterimi öğretmenlere öğrencilerin hangi seçenekte yoğunlaştıkları konusunda, öğrencilere ise kendi yanıtını sınıf açısından değerlendirme fırsatı vermektedir.

\section{Veri Toplama Araçlan}

Araştırmada kullanılan veri toplama araçlarından biri Bindak'ın (2005) ilköğretim öğrencilerinin matematik kaygılarını ölçmek için geliştirdiği Likert tipindeki matematik kaygı ölçeğidir. Ölçek 9 maddesi olumlu bir maddesi olumsuz olmak üzere 10 maddeden oluşmaktadır. Özgün ölçeğin Cronbach Alpha iç tutarlığı 0.80 olarak hesaplanmıştır. Bu araştırmada matematik kaygı ölçeğinin Cronbach Alpha iç tutarlığı ön test için .82 , son test için .86 olarak hesaplanmıştır.

Araştırmacı tarafından geliştirilen başarı testi, doğal sayılarda işlemler ünitesinin, bölme işlemi konusunda, çoktan seçmeli (dört seçenekli) ve 20 soru olarak hazırlanmıştır. Üç farklı altıncı sınıf grubuna ve toplam 137 kişiyle yapılan pilot uygulama sonrasında 2 soru testten atılmış (Madde ayırt edicilikleri .19 ve .28), 1 soru da düzeltilerek test uygulamaya hazır hale getirilmiştir. Başarı testinin madde güçlükleri .19 ile .83, madde ayıredicilikleri ise .19 ile .66 arasında değişmektedir. Başarı testi 18 soru ile son şeklini almıştır. Ön test deney, kontrol1 ve kontrol2 gruplarına $(n=72)$ uygulandıktan sonra KR-20 güvenirliği .73 olarak hesaplanmıştır. Son test verilerine göre KR-20 iç tutarlık katsayısı .82 olarak hesaplanmış ve veri toplama aracı güvenilir bulunmuştur.

\section{Verilerin Çözümlenmesi}

Deney ve kontrol gruplarının ön test ve son test başarı puanlarının karşılaştırılmasında öncelikle verilerin normal dağılıma uygunluğu incelemek amaciyla Kolmogorov-Smirnov ve Shapiro-Wilk testleri yapılmıştır. Deney ve kontrol gruplarının ön testte ve son testte başarı testlerinden alınan puanlar normal dağılmadığı için, Kruskall Wallis $\mathrm{H}$ testinden yararlanılmıştır. Matematik kaygı puanları normal dağılım gösterdiği için yinelenen ölçümler karma desenli ANOVA kullanılarak veriler çözümlenmiştir. 


\section{Bulgular}

Deney ve kontrol grupları arasında uygulama öncesinde ve sonrasinda matematik başarıları arasında anlamlı farklılık olup olmadığını belirlemede veriler normal dağılım göstermediği için Tablo 3'te verilen ve parametrik olmayan testlerden Kruskall Wallis - $\mathrm{H}$ testi uygulanmıştır. Deney ve kontrol gruplarının başarı puanlarının ön test ve son test ortalamaları Şekil 6'da görülmektedir.

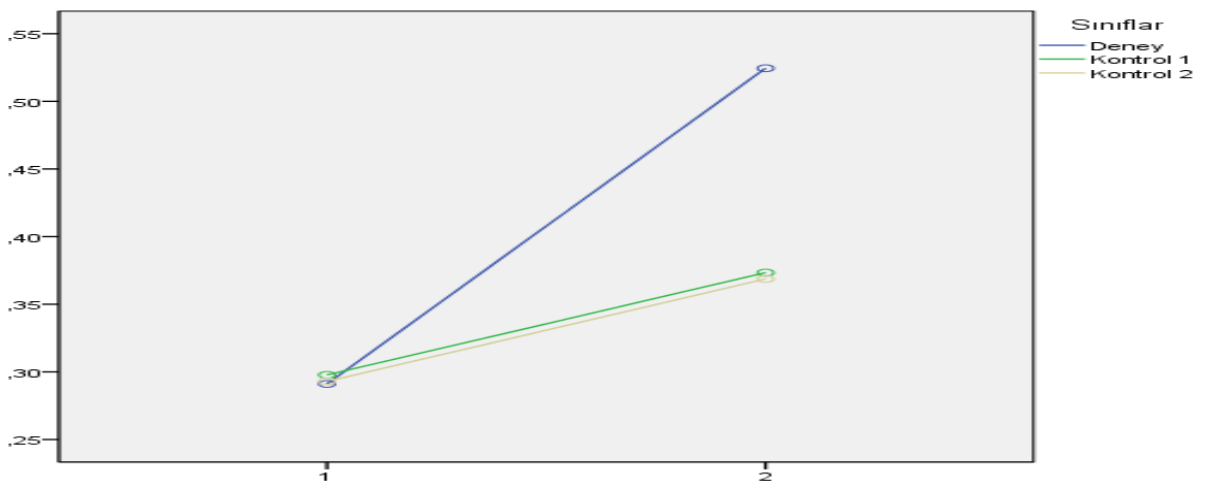

Şekil 6. Deney ve Kontrol gruplarının öntest ve sontest başarı puanları

Şekil 6'da görüldügüü üzere Deney grubu ile kontrol gruplarının ön test puanları (1. ölçüm) arasında benzerlik vardır. Bununla birlikte son testin uygulandığı 2. ölçümde deney grubunun puanının arttığı görülmektedir. Tablo 2'de bu farklılığın istatistiksel anlamlılığı incelenmiştir.

Tablo 2. Ön test ve son test başarı puanlarına yönelik Kruskal Wallis - H testi sonuçları

\begin{tabular}{lllllll}
\hline & Gruplar & $\mathrm{n}$ & S.O. & $\mathrm{X}^{2}$ & $\mathrm{Sd}$ & $\mathrm{p}$ \\
\hline Başarı Ön Test & Deney & 25 & 36.16 & & & \\
& Kontrol 1 & 25 & 37.98 & .22 & 2 & .90 \\
& Kontrol 2 & 22 & 35.20 & & & \\
Başarı Son Test & Deney & 25 & 45.84 & & & \\
& Kontrol 1 & 25 & 31.82 & 7.72 & 2 & .02 \\
& Kontrol 2 & 22 & 31.20 & & & \\
\hline
\end{tabular}


Tablo 2'ye göre grupların matematik dersi bölme konusu testinin ön testinde istatistiksel olarak anlamlı bir farklılık yoktur ( $\mathrm{p}>.05)$. Buna göre grupların bölme konusu başarısı giriş davranışlarının benzeşik olduğu belirtilebilir. Matematik dersi bölme konusu başarı testinin son test puanlarının karşılaştırılmasında ise Kruskal Wallis - $\mathrm{H}$ testinde anlamlı bir farklılık görülmüştür ( $<<.05)$. Matematik dersi bölme konusu başarı son testine göre Plickers uygulamalarının başarıya etki ettiği görülmüştür. Bu farklılıkların hangi gruplarda olduğunu belirlemek amaciyla Mann Whitney $\mathrm{U}$ testine başvurulmuş ve sonuçları Tablo 3'te verilmiştir.

Tablo 3. Gruplara göre matematik dersi bölme konusu puanlarnın Mann-Whitney U testi sonuçları

\begin{tabular}{llllllll}
\hline Gruplar & $\mathrm{n}$ & S.O. & S.T. & $\mathrm{U}$ & $\mathrm{z}$ & $\mathrm{p}$ & $\boldsymbol{\mu}$ \\
\hline Deney & 25 & 30.38 & 759.50 & 190.50 & -2.38 & .02 & -.34 \\
Kontrol 1 & 25 & 20.62 & 515.00 & & & & \\
Deney & 25 & 28.46 & 711.50 & 163.50 & -2.39 & .02 & -.35 \\
Kontrol 2 & 22 & 18.93 & 416.50 & & & & \\
\hline
\end{tabular}

Tablo 3'e göre deney grubunun matematik dersi bölme konusu sontest başarı puanı ile kontrol 1 grubunun sontest puanı arasında .05 düzeyinde orta etki büyüklügünde deney grubu lehine anlamlı farklılık görülmüştür $(\mathrm{U}=190.50 ; \mathrm{z}=-2.38 ; \mathrm{p}=.02 ; \boldsymbol{\mu}=-.34)$. Benzer şekilde deney grubunun matematik dersi bölme konusu son test başarı puanı ile kontrol 2 grubunun sontest puanı arasında .05 düzeyinde orta etki büyüklügünde deney grubu lehine anlamlı farklılık görülmüştür $(U=163.50 ; z=-2.39 ; p=.02 ; \mu=-$ .35).

Deney ve kontrol grupları arasında uygulama öncesinde ve sonrasında matematik kaygıları arasında anlamlı farklılık olup olmadığını belirlemek için oluşturulan ikinci alt problemin verilerini incelemek amaciyla yinelenen ölçümlerde karma desenli ANOVA testi uygulanmıştır. Şekil 7'de deney ve kontrol gruplarının ön test ve son test matematik kaygi puanlarının ortalamaları görülmektedir. 


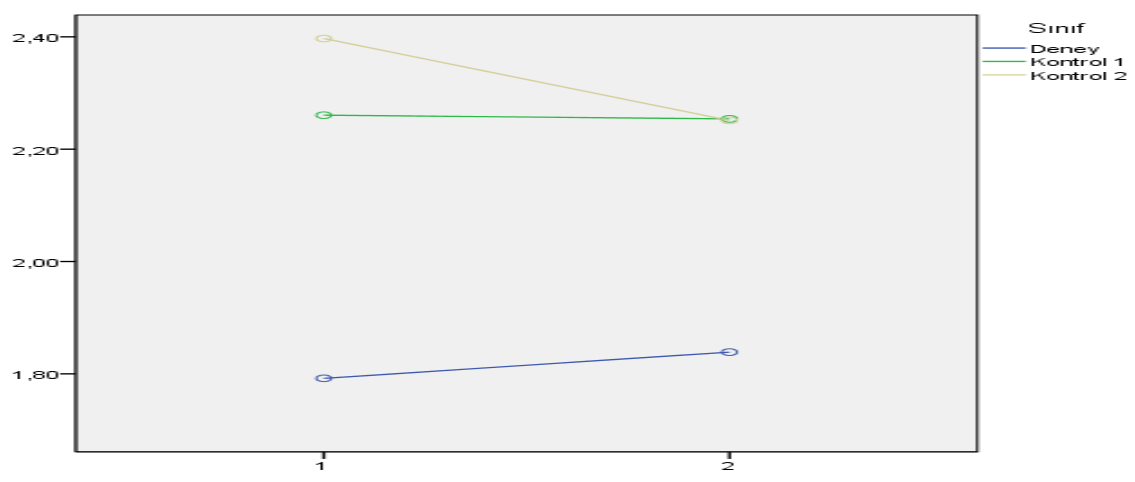

Şekil 7. Deney ve kontrol gruplarmin öntest ve sontest kaygı puanları

Şekil 7'ye göre deney grubunun matematik kaygı puanlarının kontrol 1 ve kontrol 2 gruplarına göre hem ön testte hem de son testte düşük olduğu belirtilebilir. Bununla birlikte bu farklılığın istatistiksel olarak anlamlılığını test etmek için karma desenli ANOVA yapılmıştır.

Tablo 4. Matematik kaygısı için yinelenen ölçümlerde karma desenli ANOVA sonuçları

\begin{tabular}{llllll}
\hline Varyansın kaynağ 1 & K.T. & $\mathrm{Sd}$ & K.O. & $\mathrm{F}$ & $\mathrm{p}$ \\
\hline Gruplar arası & & & & & \\
\hline Grup & 7.41 & 2 & 3.706 & 3.483 & .04 \\
\hline Hata & 73.41 & 69 & 1.064 & & \\
\hline Gruplar içi & & & & & \\
\hline Ölçüm & .05 & 1 & .05 & .25 & .62 \\
\hline Ölçüm ${ }^{*}$ Grup & .23 & 2 & .11 & .65 & .53 \\
\hline Hata & 12.21 & 69 & .18 & & \\
\hline
\end{tabular}

Tablo 4'e göre, ölçüm ve grupların etkileşimi bağlamında bu farklılığın anlamlı olmadığ görülmüştür $\left(\mathrm{F}_{(2,69)}=.65 ; \mathrm{p}>.05\right)$.

Plickers uygulamasının deney grubu ön test ve son test kaygı puanları arasında anlamlı farklılık olup olmadığını belirlemek amacıyla bağımlı gruplar $\mathrm{t}$ testi yapılmıştır. Bu analize yönelik sonuçlar Tablo 5'de verilmiştir. 
Tablo 5. Deney grubunun matematik kaygı puanlarının incelenmesi

\begin{tabular}{llllllll}
\hline & Ölçüm & $\overline{\mathrm{X}}$ & ss & $\mathrm{sd}$ & $\mathrm{t}$ & $\mathrm{p}$ & $\boldsymbol{\mu}$ \\
\hline $\begin{array}{l}\text { Matematik } \\
\text { Kayg1 }\end{array}$ & Ön test & 1.79 & .71 & \multirow{2}{*}{24} & \multirow{2}{*}{-.34} & \multirow{2}{*}{.74} & \multirow{2}{*}{ - } \\
\cline { 2 - 5 } & Son test & 1.84 & .83 & & & \\
\hline
\end{tabular}

Matematik kaygı ön test ve son test puanları arasında anlamlı bir fark yoktur $\left(\mathrm{t}_{(24)}=-.34 ; \mathrm{p}>.05\right)$.

\section{Sonuç ve Tartışma}

Araştırma sonucunda Plickers uygulamasının matematik dersi bölme konusu başarısını olumlu etkilediği görülmüştür. Deney ve kontrol gruplarının ön test başarı puanları büyük benzerlik gösterirken, son test puanları incelendiğinde, kontrol1 ve kontrol2 gruplarının son test puan ortalamalarının, birbirine çok yakın olduğu görülmüştür. Kontrol gruplarındaki sontest puan düşüşlerinin nedeni olarak yürütülen etkinliklere öğrencilerin verdikleri duyuşsal tepkiler görülmektedir. Yeni bir uygulamayla karşılaşan öğrencilerin bu yeni uygulamanın başarı puanlarına nasıl yansıyacağı konusunda heyecanlı ve farklı beklentiler içinde olabilecekleri düşünülmektedir. Dolayısıyla yapılacak yeni araştırmalarda öz-yeterlik, tutum gibi ek değişkenlerin işe koşulmasında yarar görülmektedir. Deney grubunun son test başarı puanlarındaki artışı ise Plickers uygulamalarının sağladığı düşünülmektedir. Kontrol gruplarının benzer düzeyde aldıkları başarı testi puanları, deneysel işlemin etkili olduğunu göstermektedir. Bu durum, Plickers uygulamasının öğrenme eksikliklerini tespit etmede ve başarıyı arttırmada etkili olduğuna kanıt oluşturmaktadır. Öğrenme eksiklikleri öğretim sürecindeki her uygulamada gözlenebilmiştir. Elde edilen bulgular alan ayazındaki bazı çalışmalarla paraleldir. Dunham (2011) yedinci sınıf matematik başarısı, ön test son test deneysel desende, öğrenci yanıt sistemlerini kullanan grupların başarısının anlamlı ölçüde yükseldiğini belirlemiştir. Benzer bulgular Chou (2017) tarafından da elde edilmiş, Plickers uygulamasının öğrenci başarı puanlarında bir atışa neden olup olmayacağı araştııılmıştır. Araştırma sonucunda Plickers'ın bir telafi öğretim yaklaşımı olarak etkili bulunduğu belirlenmiştir. Ortiz (2014) ise öğrenci yanıt sistemini pisagor teoreminin öğretilmesinde kullanmıştır. Yapılan deneysel çalışmada 
öğrenci yanıt sistemleri derse katılımı anlamlı biçimde arttırırken, öğrenci başarısına anlamlı bir etki yapmamıştır. Berry (2009), yaptığı araştırma sonucu sınıf yanıtlama sistemlerinin akademik başarıyı arttırdığı, öğrencilerin uygulamayı eğlenceli buldukları ve derse katılımlarının arttığını ifade ederken, Patterson vd. (2009) büyük sınıf ortamlarında sinıf yanıtlama sistemlerinin öğrenci başarısına etkisinin olmadığı ancak öğrencilerin derse katılım derecelerini arttırdığı sonucuna ulaşmıştır (Akt: Bolat, Şimşek ve Ülker, 2017). Zengin, Bars ve Şimşek (2017) yaptıkları çalışmada, matematik öğretmeni adaylarının Kahoot! ve Plickers'ı uygulamalarına yönelik görüşlerine göre, bu yazılımların matematik öğretiminin biçimlendirici değerlendirme sürecinde kullanılmasında ayrıntılı veri analizi sunması, zamandan tasarruf sağlaması, derse katılımı arttırması, dersi oyunlaştırması ve eğitimde teknoloji entegrasyonu yeterliği sağlaması bakımından bir çok olumlu katkıları olduğu sonucuna ulaşmışlardır. Thomas vd. (2016) ise Plickers uygulamasını özellikle yaratıcılık ve etkin katılım açısından etkili bulmuşlardır. Wood, Brown ve Grayson (2017) ise Plickers uygulamasını keyifli ve etkileşimli olması nedeniyle yararlı buldukları sonucunu rapor etmiştir. Ancak MacCargo (2017) Plickers uygulamasına daha temkinli yaklaşmış, akademik başarı hedefleri bakımından alan yazındaki bazı çalışmalarda geçen olumlu etki bulgularını doğrulamamıştır.

Araştırmanın sonucunda, Plickers uygulamasının matematik kaygısına etki etmediği görülmüştür. Ön test ve son test matematik kayg1 puan ortalamalarında en düşük ortalamaya sahip olan deney grubunun, oldukça düşük düzeyde matematik kaygısı yaşadıkları görülmüştür. Bu noktada deney grubunun sınıf iklimi hakkında bilgilendirme ihtiyacı doğmaktadır. Araştırmacı gözlemlerine göre, öğretmen deney grubundaki öğrencilerle daha iyi bir iletişim kurmakta, kontrol gruplarına göre daha az rekabetçi bir sınıf ortamı bulunmaktadır. Bu ortam, öğrencilerin kendilerini rahat ve güvende hissetmelerini sağlayarak, matematik dersine ilişkin kaygı duymalarını azaltmış olabilir.

Kontrol gruplarındaki son test başarı puanlarındaki düşüşlerin bir nedeninin kaygı olabileceği düşünülmektedir. Bu nedenle bu araştırmaya çalışma grubu benzerliği olan araştırmalar önem arz etmektedir. Alanyazında ortaokul öğrencilerinin matematik kaygılarının incelendiği araştırmalarda, öğrencilerin benzer düzeyde kaygı puan ortalamalarına 
sahip oldukları görülmüştür. Taşdemir'in (2015) ortaokul öğrencilerinin matematik kaygı düzeylerini incelediği çalışmasında, 5. sınıf öğrencilerinin matematik kaygı puan ortalamalarının $(1,80)$ olarak hesaplandığı görülmüştür. Ayrıca, Tuncer ve Yılmaz (2016)'ın ortaokul öğrencilerinin matematik dersine yönelik tutum ve kaygılarına ilişkin görüşlerinin değerlendirildiği çalışmasında, 6. sınıf öğrencilerinin matematik kaygı puan ortalamaları $(1,86)$ olarak hesaplanmıştır. Sakal'ın (2015) birçok değişkene göre matematik kaygısını incelediği çalışmada da 4. sınıf öğrencilerinin matematik kaygı düzeylerinin düşük olduğu görülmüştür. Dursun ve Bindak'ın (2011) ilköğretim II. kademe öğrencilerinin matematik kaygılarını inceledikleri çalışmada da benzer sonuçlar ortaya çıkmıştır. Matematik kaygı düzeylerinin düşüklügünü gösteren bu sonuçlar, matematik kaygısının, genellikle ilköğretim ve ortaöğretim seviyelerinde yaşanılan çeşitli olumsuz deneyimlerle ortaya çıktığını (Harper ve Dane, 1998; Jackson ve Leffingwell, 1999; Akt: Bekdemir, 2009) desteklemektedir. Kaygı düzeylerinin yıllar geçtikçe arttığı, ergenlik çağında daha belirgin bir şekilde gözlemlendiği belirtilmektedir (Bander ve Betz, 1981; Akt: Aydın Yenihayat, 2007).

Marshall vd. (2017) öğrenci görüşlerine dayandırdıkları araştırma bulguları arasında Plickers uygulamasını matematik kaygısının azaltmada faydalı olabileceğini rapor etmişlerdir. Çoruk ve Çakır'ın (2017) 4. sınıf matematik dersi kesirler konusunda hazırlanan çoklu ortamların öğrencilerin akademik başarı düzeylerine, matematik kaygı düzeylerine etkisini araştırdıkları çalışmada, deney ve kontrol gruplarının matematik dersine yönelik kaygı ön test düzeylerinin düşük olduğu görülmüştür. Aynı araştırmanın son test kaygı düzeyleri incelendiğinde, deney ve kontrol gruplarının kaygı düzeylerinde artış olduğu ancak bu artışın anlamlı olmadığı sonucuna ulaşılmıştır. Araştırmamızda deney grubunun son test kaygı puanında çok az artış olduğu, 1. kontrol grubunun kaygı puanının değişmediği ve 2 . kontrol grubunu kayg1 puanlarının azaldığ gözlemlenmiştir, bu sonuçlar istatistiki olarak anlamlı bulunmamıştır. Deney grubunda araştırma öncesine göre matematik kaygı puanlarında az da olsa artışın olması, akla araştırma ortamının öğrencilere baskı oluşturabileceği ihtimalini getirmektedir. Yurtbakan, İskenderoğlu ve Sesli (2016), matematik ders başarını arttırma yolları olarak ders tekrarı, 
aile desteği, pekiştirici etkinlikler ve matematik uygulama alanlarının oluşturulması gibi bulgular rapor etmişlerdir.

Alanyazında matematik başarısı ve matematik kaygısı arasındaki ilişkiyi açıklayan birçok çalışma bulunmaktadır. Bu araştırmada matematik başarısı ve matematik kaygısı arasındaki ilişki değerlendirilirken, deney ve kontrol gruplarının hem ön test hem de son test kaygı düzeylerinin "katılmıyorum" aralığında olması, puanlardaki değişimlerin anlamlı bulunamaması başarı ve kaygıyı yorumlamayı sınırlandırmıştır.

Alanyazında yer alan bazı araştırmalarda (Yenilmez ve Özbey, 2006; Kutluca, Alpay ve Kutluca, 2015) bu araştırma bulgularına paralel olarak matematik başarısı ile matematik kaygısı arasında negatif bir ilişkinin var olduğu sonucuna ulaşılmıştır. Kaygı ve öğrenme arasındaki ilişkinin, güdülenme ve başarı arasındaki ilişkiye benzediği ve öğrenilmesi gereken durum veya konu kolaysa yüksek kaygının öğrenmeyi hızlandırırken, öğrenilen malzeme karmaşık ve zorsa, yüksek kaygının öğrenmeyi zorlaştırdığı ve yavaşlattığı bilinmektedir. Cates ve Ryhmes'ın (2003) çalışmasının bulguları ise yüksek matematik kaygısına sahip öğrenci grubunun, temel matematiksel işlem testlerinden (toplama, çıarma, çarpma, bölme ve lineer denklemler) düşük matematik kaygısına sahip öğrenci grubuna göre anlamlı düzeyde daha düşük puan aldığını göstermektedir. Hembree (1990) tarafından yapılan bir meta analizde 151 çalışmada matematik kaygısı ile matematik başarısı arasında negatif yönde ilişki bulunmuştur. Buna göre matematik kaygısı yüksek olanların matematik başarıları düşüktür. Ma (1999) tarafından yapılan bir başka meta analizde 26 çalışma incelenmiş ve başarı ile kaygı arasında anlamlı ve negatif yönde ilişki bulunmuştur (Arslan, 2008).

\section{Öneriler}

Araştırmada, Plickers uygulamasının ortaokul beşinci sınıf matematik dersinde öğrencilerin başarılarını anlamlı derecede etkilediği görülmüştür. Plickers uygulaması, öğrencilerin soru çözüm aşamalarını gösteren bir uygulama olmadığı için, kazanımlar sonrası genel bir değerlendirmenin yapılmasını sağlamaktadır. Bu nedenle öğrencilerin problem çözme süreçlerinin izlenmesinde başka değerlendirme yaklaşımlarına başvurulmalıdır. 
Plickers uygulaması, tüm öğrenci yanıtlarını kaydederek, öğretmene öğrencilerin zaman içerisindeki gelişimleriyle ilgili fikirler vermektedir. Öğretmenler, bu fikirler yoluyla, sınıf içerisinde bireysel farklılıklara göre bir öğretim planı tasarlayabilirler.

Bu araştırma Doğal Sayılarda İşlemler Ünitesinin Bölme İşlemi konusuyla sınırlandırılmıştır ve Plickers uygulaması yalnızca üç hafta boyunca bazı derslerde yapılmıştır. Araştırmacılar daha uzun süreli çalışmalarda, Plickers uygulamasının etkisini, olumlu ve olumsuz yönlerini araştırılabilir. Bunun yanında bu çalışmada ön koşul öğrenmelerin sıklıkla yer aldığı Matematik dersi seçilmiştir. Plickers uygulaması diğer derslerde de kullanılarak, başarıya etkisi araştırılabilir.

Plickers uygulamalarında, çoktan seçmeli ve doğru yanlış soru türlerinden yararlanılmaktadır. Öğretmenler, hem öğrenmeleri değerlendirmede hem de cevapların doğru ya da yanlış olmadığı sadece öğrenci görüşlerinin alınabileceği durumlarda da Plickers uygulamaları yapabilirler. Öğretmenler derste fikir yürütme amaciyla, Plickers uygulamalarını daha yapılandırıcı bir biçimde kullanılabilir. Bu araştırmada, Plickers uygulamasının etkililiği araştırıldığı için matematik öğretmenin öğretim yöntem ve tekniklerine ve geri bildirim tekniklerine müdahale edilmemiştir. Diğer çalışmalarda, sınıf başarı yüzdesine uygun geri bildirim teknikleri verilerek öğrenmeye etkisi araştırılabilir.

Araştırma kapsamında Plickers uygulamasının matematik kaygısı anlamında manidar bir fark yaratmadığı belirlenmiştir. Bu nedenle Plickers uygulamasının matematik öğretiminde rahatlıkla uygulanabileceği belirtilebilir. 


\title{
EXTENDED ABSTRACT
}

\section{The Effect of Plickers Application on Anxiety and Achievement in Secondary School 5th Mathematics Lesson about the subject of Division}

\author{
* \\ Murat Tuncer - Manolya Şimşek \\ Firat University, National Education Ministry
}

Mathematics, which is regarded as one of the basic courses at every level of education starting from primary school, has a distinctive and decisive character in all exams made at national level. However, it is seen that the mathematical averages of our country are quite low in national (YGS, TEOG etc.) and international (PISA, TIMSS) exams (Berkant and Gençoğlu, 2015). Given mathematics lesson in from primary level to university level in Turkey does not meet the expectation in terms of academic achievement when it is considered the quantity of this courses at schools. One of the solutions that comes to mind about increasing mathematics success is the support of technology as learning setting and design of the course. In this research, it was investigated whether the success of mathematics course could be increased by Plickers application. As the interactivity of mobile devices increases and the use of these devices in the learning-teaching process becomes widespread, the pedagogical superiority and benefits of these devices can be understood. The advantages of using the ICT in the learning-teaching process of can be seen obviously on every corner of education.

In the study, unequal pre-test and post-test control group semi-experimental design was utilized. To collect data, pre-test and post-test, the achievement test and mathematics anxiety scale were used. The research group is composed of 72 students from three different fifth grade group of a secondary school in Diyarbakır in 2017-2018 academic year. Groups were determined through simple unselected method. Accordingly, an experiment and two control groups constitute the research group of the research. 
As a result of the research, it was seen that Plickers application positively affected the success of the subject of division in mathematics lesson. It has been observed that in the Plickers application, the rate of the class success increases gradually when similar questions are asked in succession. However, Plickers' application did not seem to affect mathematical anxiety. It was observed that the experimental group having the lowest average scores of pre-test and post-test math anxiety scores experienced a very low level of math anxiety.

Obtained findings are parallel to some studies in the field. For example, Dunham (2011) determined that the success of 7 th grade students in math, through pre-test post-test experimental design, increased significantly by using student's response system. Similar findings were also obtained by Chou (2017), and it was investigated whether the Plickers application would cause an increase in student's achievement scores. As a result of the research, Plickers was found to be effective as a compensatory teaching approach. Ortiz (2014) used the student response system in teaching Pythagorean theorem. While the student response systems in the experimental study significantly increased participation in the lesson, this did not make a significant impact on his / her success. Berry (2009) argues that researcher-level class response systems enhance academic success, while students find the practice more enjoyable and increase their attendance in class, Patterson et al. (2009) found that classroom response systems did not have an impact on student achievement in large class settings, but they increased students' attendance levels (Cit. Bolat, Şimşek and Ülker, 2017). Rich, Bars, and Lightning (2017) working on math teacher candidate's Kahoot! and Plickers have concluded that these softwares provide a lot of positive contributions in providing detailed data analysis of the use of mathematics teaching in the formative assessment process, providing time savings, enhancing classroom participation, lesson play and technology integration in education. Thomas et al. (2016) found that Plickers application was particularly effective in terms of creativity and participation. Wood, Brown, and Grayson (2017) reported the results they found were useful because of the pleasurable and interactive nature of the Plickers application. However, MacCargo (2017) has been more cautious about the Plickers application and has not confirmed the positive impact found in some studies in the field of academic achievement goals. 
In the study, it was observed that the Plickers application significantly affected the achievement of students in the 5th grade math class in secondary school. The Plickers application provides a general evaluation of the learners' learning after the achievements, since it is not an application that shows the process of solving the question. For this reason, other evaluation approaches should be used in monitoring the problem solving process of the students. In addition, the Plickers application records all student responses, giving ideas about how teachers develop over time. Through these ideas, teachers can design a teaching plan according to individual differences within the classroom.

This research was restricted to the Division of Operations Unit of Natural Numbers, and the Plickers application was applied in some lessons for only three weeks. If researchers work longer, they can investigate the impact, positive and negative aspects of the Plickers application. In addition to this, Mathematics course, where pre-requisite learning frequently takes place, was chosen in this study. By using Plickers application in other lessons, the effect can be searched successfully.

\section{Kaynakça / References}

Albayrak, M. ve Şimşek, M. (2017). Yetişkinlerin davranışlarını değiştirmenin güçlüğü: Bölme örneği. Erzincan Üniversitesi Eğitim Fakültesi Dergisi, 19(1), 184-198.

Alkan, V. (2011). Etkili matematik öğretiminin gerçekleştirilmesindeki engellerden biri: kaygı ve nedenleri. Pamukkale Üniversitesi Eğitim Fakültesi Dergisi, 29(1), 89-107.

Altun, M. (2001). Matematik öğretimi. İstanbul: Alfa Basım.

Arslan, A. (2008). Web destekli öğretimin ve öğretimsel materyal kullanımının öğrencilerin matematik kaygısına, tutumuna ve başarısına etkisi. Yayımlanmamış Doktora tezi, Marmara Üniversitesi, İstanbul.

Atılgan, H. (2011). Değerlendirme ve not verme. H. Atılgan (Ed.). Eğitimde Ölçme Ve Değerlendirme İçinde (349-395), Ankara: Anı Yayıncılık.

Aydın-Yenihayat, S. (2007). Ilköğretim öğrencilerinin matematik kaygısı ile öğretmen tutumları arasındaki ilişkinin değerlendirilmesi. Yayımlanmamış Yüksek Lisans Tezi. Yedi Tepe Üniversitesi, İstanbul.

Aydın, E., Delice, A., Dilmaç, B. ve Ertekin E. (2009). İlköğretim matematik öğretmen adayların matematik kaygı düzeylerine cinsiyet, sınıf ve kurum değişkenlerinin etkileri. İlköğretim Online, 8(1), 231-242. 
Aydın, B. (2003). Bilgi toplumu oluşumunda bireylerin yetiştirilmesi ve matematik öğretimi. Pamukkale Üniversitesi Ĕ̆itim Fakültesi Dergisi, 14, 183190.

Aydın, M. ve Keskin, İ. (2017). 8. Sınıf öğrencilerinin matematik kaygı düzeylerinin bazı değişkenler açısından incelenmesi. Kastamonu Eğitim Dergisi, 25(5), 1801-1818.

Aysan, F., Tanriöğen, G. ve Tanrı̈ğgen, A. (1996). Perceived causes of academic failure among the students at the faculty of education at Buca. Yayımlandığ1 Kitap (G. Karagözoğlu Ed.), Teacher Training for The Twenty First Century. İzmir: Buca Eğitim Fakültesi Yay.

Ayvaz, A. (2010). 4. Sınıf matematik dersi bölme işlemi alt öğrenme alanının edebi ürünlerle işlenmesinin öğrenci başarısı ve tutumuna etkisi. Yayımlanmamış Yüksek Lisans Tezi. Sakarya Üniversitesi, Sakarya.

Baydar, S. C. ve Bulut, S. (2002). Öğretmenlerin matematiğin doğası ve öğretimi ile ilgili inançlarının matematik eğitimindeki önemi. Hacettepe Üniversitesi Ĕ̆itim Fakültesi Dergisi, 23, 62-66.

Bekdemir, M. (2007). İlköğretim matematik öğretmen adaylarındaki matematik kaygısının nedenleri ve azaltılması için öneriler :Erzincan Eğitim Fakültesi örneği. Erzincan Eğitim Fakültesi Dergisi, 9(2), 131-144.

Bekdemir, M. (2009). Meslek yüksekokulu öğrencilerinin matematik kayg1 düzeylerinin ve başarılarının değerlendirilmesi. Erzincan Üniversitesi Fen Bilimleri Enstitüsü Dergisi, 2(2), 169-189.

Berkant, H.G. ve Gençoğlu, S.Ş. (2015). Farklı lise türlerinde çalışan matematik öğretmenlerinin matematik eğitimine yönelik görüşleri. Kahramanmaraş Sütçü İmam Üniversitesi Sosyal Bilimler Dergisi, 12(1), 194- 217.

Bichsel, J. (2012). Analytics in Higher Education: Benefits, Barriers, Progress, and Recommendations (Research Report), Louisville, CO: EDUCAUSE Centre for Applied Research. Xx.xx.xxxx tarihinde http://net.educause.edu/ir/library/pdf/ERS1207/ers1207.pdf adresinden erişilmiştir.

Bindak, R. (2005). İlköğretim öğrencileri için matematik kaygı ölçeği. Fırat Üniversitesi Fen ve Mühendislik Bilimleri Dergisi,17(2), 442-448.

Bloom, B. (1979). İnsan nitelikleri ve okulda öğrenme (Çev. D. A. Özçelik). Ankara: MEB.

Bolat, Y. İ., Şimşek, Ö. ve Ülker, Ü. (2017). Oyunlaştırılmış çevrimiçi sınıf yantlama sisteminin akademik başarıya etkisi ve sisteme yönelik 
görüşler. Abant İzzet Baysal Üniversitesi Ĕ̆itim Fakültesi Dergisi, 17(4), 1741-1761.

Chou, C.C., (2017). An analysis of the 3D video and interactive response approach effects on the science remedial teaching for fourth grade underachieving students. EURESIA Journal of Mathematics Science and Technology Education, 13(4), 1059-1073.

Çoruk, H. ve Çakır, R. (2017). Çoklu ortam kullanımının ilkokul öğrencilerinin akademik başarılarına ve kaygılarına etkisi. Turkish Journal of Computer and Mathematics Education, 8 (1), 1-27.

Dede, Y. ve Dursun, Ş. (2008). İlköğretim II. kademe öğrencilerinin matematik kayg1 düzeylerinin incelenmesi. Uludă̆ Üniversitesi Eğitim Fakültesi Dergisi, 21(2), 295-312.

Deniz, L. ve Üldaş, İ. (2008). Öğretmen ve öğretmen adaylarına yönelik matematik kaygı ölçeği'nin geçerlilik güvenilirlik çalışması. Eurasian Journal of Educational Research, 30, 49-62.

Dunham, V. K. (2011, January 1). The impact of a student response system on academic performance. ProQuest LLC, 1, 1-95. Doctor of Education. South Carolina State University. Orangeburg, South Carolina.

Dursun, Ş. ve Bindak, R. (2011). İlköğretim II. kademe öğrencilerinin matematik kaygilarının incelenmesi. Cumhuriyet Üniversitesi Sosyal Bilimler Dergisi, 35(1), 18-21

Dursun, Ş. ve Dede, Y. (2004). Öğrencilerin matematik başarısını etkileyen faktörler: Matematik öğretmenlerinin görüşleri bakımından. Gazi Eğitim Fakültesi Dergisi, 24(2), 217-230.

Eng, T.H., Li, V.L. ve Julaihi, H. (2010). The relationships between students' underachievement in mathematics courses and influencing factors. Procedia Social and Behavioral Sciences, 8, 134-141.

Gelbal, S., ve Kelecioğlu, H. (2007). Öğretmenlerin ölçme ve değerlendirmeyöntemleri hakkındaki yeterlik algıları ve karşılaştıkları sorunlar. Hacettepe Üniversitesi Ĕ̈itim Fakültesi Dergisi, 33, 135-145.

Gerez-Cantimer, G. ve Şengül, S. (2016). Ortaokul 6., 7. ve 8. Sınıf öğrencilerinin matematik dersine yönelik kaygıları ve dersi değerlendirmeleri. The Journal of Academic Social Science Studies,48, 261-282 Doi number:http://dx.doi.org/10.9761/JASSS3542

İlhan, M. ve Öner-Sünkür M. (2012). Matematik kaygısı ile olumlu ve olumsuz mükemmeliyetçiliğin matematik başarısını yordama gücü. Mersin Üniversitesi Ĕ̆itim Fakültesi Dergisi, 8(1), 178-188. 
Işık, A., Çiltaş, A. ve Bekdemir, M. (2008). Matematik eğitiminin gerekliliği ve önemi. Atatürk Üniversitesi Kazım Karabekir Ĕ̆itim Fakültesi Dergisi, 17, 174-184.

Keçeci, T. (2011). Matematik kaygısı ve korkusu ile mücadele yolları. 2 nd International Conference on New Trends in Education and Their Implications, 27-29 Nisan 2011, Antalya.

Köğce, D. (2012). Illköğretim matematik öğretmenlerinin geri bildirim verme biçimlerinin incelenmesi. Doktora tezi, Karadeniz Teknik Üniversitesi, Trabzon.

Krause, J.M., O'neil, K. ve Dauenheuer, B. (21017). Plickers: A formative assessment tool for k-12 and pete professionals. Strategies, 30(3), 30-36, DOI: $10.1080 / 08924562.2017 .1297751$

Kutluca, T., Alpay, F.N. ve Kutluca, S. (20159. 8.sınıf öğrencilerinin matematik kayg1 düzeylerine etki eden faktörlerin incelenmesi. Dicle Üniversitesi Ziya Gökalp Ĕ̈itim Fakültesi Dergisi, 25, 202-214.

Lebens, M., Graff, M. ve Mayer, P. (2011). The affective dimensions of mathematical difficulties in schoolchildren. Education Research International, 20, 1-13.

Luckin, R., Clark, W., Avramides, K., Hunter, J. ve Oliver, M. (2017). Using teacher inquiry to support technology-enhanced formative assessment: a review of the literature to inform a new method. Interactive Learning Environments, 25(1), 85-97

Marshall, E.M., Rachel, V.S., Wilson, D.A. ve Mann, V.E. (2017). Addressing maths anxiety and engaging students with maths within the curriculum. Ocak 2017 tarihinde https://www.sheffield.ac.uk/polopoly_fs/1.695097!/file/Marshall_Staddon_Wilson_Mann_Addressing_maths_anxiety_within_curriculum.pdf adresinden erişilmiştir.

McCargo, M.G. (2017). The effect of Plickers as response cards on academic engagement behavior in high school students. Master's Thesis, University of Southern Mississippi Deparment of Psychology.

National Council of Teachers of Mathematics (2000). Principles and standards for school mathematics. Reston, VA. The National Council of Teachers of Mathematics, Inc.

Ortiz, B. L. (2014). The effects of student response systems on student achievement and engagement. Unpublished master of science thesis. California State Polytechnic University, Pomona. 
Ozan, C. (2017). Biçimlendirici değerlendirmelerin öğrencilerin akademik başarı, tutum veöz düzenleme becerilerine etkisi. Yayımlanmamış Doktora tezi, Atatürk Üniversitesi, Erzurum.

Peker, M., Şentürk, B. (2012). İlköğretim 5. sınıf öğrencilerinin matematik kaygılarının bazı değişkenler açısından incelenmesi. Dumlupınar Üniversitesi Sosyal Bilimler Dergisi, 34, 21-32.

Redecker, C. (2017). European framework for the digital competence of educators: DigCompEdu. (Y. Punie ed). EUR 28775 EN. Publications Office of the European Union, Luxembourg.

Sakal, M. (2015). İlkokul 4. sınıf öğrencilerinin bazı psiko-sosyal değişkenlere göre matematik kaygısının incelenmesi. Yayımlanmamış Yüksek lisans tezi, Dokuz Eylül Üniversitesi, İzmir.

Sidekli, S., Gökbulut, Y. ve Sayar, N. (2013). Dört işlem becerisi nasıl geliştirilir. Uluslararası Türk Eğitim Bilimleri Dergisi, 1(1), 31-41

Şimşek, Ö., Bars, M. ve Zengin, Y. (2017). Matematik öğretiminin ölçme ve değerlendirme sürecinde bilgi ve iletişim teknolojilerinin kullanımı. Uluslararası Eğitim Programları ve Öğretim Çalısmaları Dergisi, 7(13), 189-207.

Singh, K., Granville, M. ve Dika, S. (2002). Mathematics and science achievement: Effects of motivation, interest, and academic engagement, The Journal of Educational Research,95(6), 323-332.

Suan, J.S. (2014). Factors affecting underachivement in mathematics. Proceeding of the Global Summit on Education GSE 2014 (E- ISBN 978-96711768-5-6) 4-5 March 2014, Kuala Lumpur, MALAYSIA.

Taşdemir, C. (2015).Ortaokul öğrencilerinin matematik kaygı düzeylerinin incelenmesi.Batman Üniversitesi Yaşam Bilimleri Dergisi, 5 (1), 1-12.

Tekin, E.G. (2010). Matematik eğitiminde biçimlendirici değerlendirmenin etkisi. YayımlanmamışYüksek Lisans Tezi. Marmara Üniversitesi, İstanbul.

Thomas, J.R., Lppez-Fernandez, V., Llamas-Salguero, F. ve Martin-Lobo, P. (2016). Participation and knowledge through in high school students and its relationship to creativity. UNESCO-UNIR ICT \& Education Latam Congress, 22-24 June 2016, Russia.

Toluk Uçar, Z., Pişkin, M., Akkaş, E. N. ve Taşçı, D. (2010). İlköğretim öğrencilerinin matematik, matematik öğretmenleri ve matematikçiler hakkındaki inançları. Ĕ̆itim ve Bilim, 35(155), 131-144. 
Tuncer, M. ve Yılmaz, Ö. (2016).Ortaokul öğrencilerinin matematik dersine yönelik tutum ve kaygılarına ilişkin görüşlerinin değerlendirilmesi. KSÜ Sosyal Bilimler Dergisi, 13(2), 47-64.

Türkdoğan, A. (2011). Yanlışın anatomisi: Ilköğretim matematik sınıflarından öğrencilerin yaptıkları yanlışlar ve öğretmenlerin dönütlerinin analitik incelenmesi. Yayımlanmamış Doktora tezi, Karadeniz Teknik Üniversitesi, Trabzon.

Ural, A. (2015). Matematik öz yeterlik algısının matematik öğretmeye yönelik kaygıyaetkisi. Kuramsal Eğitimbilim Dergisi, 8(2), 173-184.

Varol, F. ve Kubanç, Y. (2015). Öğrencilerin bölme işlemi gerektiren aritmetik sözel problemlerde yaşadığı zorlukların incelenmesi. Ondokuz Mayıs Üniversitesi Eğitim Fakültesi Dergisi, 34(1), 99-123.

Wood, T.A., Brown, K. ve Grayson, M. (2017). Faculty students perceptions of plickers. ASEE Zone II Conference, 2-5 March 2017, Puerto Rico.

Yazar, T. ve Şimşek, Ö. (2017). Çoklu zeka kuramı ve yapılandırmacılık. (B. Oral ve T. Yazar Ed.). Eğitimde program geliştirme ve değerlendirme içinde (367-398), Ankara: Pegem Akademi.

Yenilmez, K. ve Kakmacı, Ö. (2008). İlköğretim yedinci sınıf öğrencilerinin matematikteki hazır bulunuşluk düzeyi. Kastamonu Eğitim Dergisi, 16(2), 529-542

Yenilmez, K. ve Özbey, N. (2006). Özel okul ve devlet okulu öğrencilerinin matematik kaygı düzeyleri üzerine bir araştırma. Uludağ Üniversitesi Eğitim Fakültesi Dergisi, 19(2), 431-448.

Yetgin, O. (2017). Ortaöğretim öğrencilerinin matematik kaygısı ve öğrenmeye ilişkin tutumlarının incelenmesi. Yayımlanmamış Yüksek Lisans Tezi. Adıyaman

Yilmaz, H. R. ve Bindak, R. (2016).Ortaokul öğrencilerinde matematik başarısının matematik kaygısı, sınav kaygısı ve bazı demografik değişkenlerle ilişkisinin incelenmesi. MSKU Ĕ̆itim Fakültesi Dergisi, $3(2), 30-42$.

Yurtbakan, E., İskenderoğlu, T.A. ve Sesli, E. (2016). Öğrencilerin matematik derindeki başarılarını attırma yolları konusunda sınıf öğretmenlerinin görüşleri. Ondokuz Mayıs Üniversitesi Ĕ̆itim Fakültesi Dergisi, 35(2), 101-119.

Zengin, Y., Bars, M. ve Şimşek, Ö. (2017).Matematik öğretiminin biçimlendirici değerlendirme sürecinde Kahoot! ve Plickers uygulamalarının incelenmesi. Ege Eğitim Dergisi, 18(2), 602-626. 


\section{Kaynakça Bilgisi / Citation Information}

Tuncer, M. ve Şimşek, M. (2019). Ortaokul beşinci sınıf matematik dersi bölme işlemi konusunda plickers uygulamasının matematik kaygısına ve matematik başarısına etkisi.OPUS-Uluslararası Toplum Araştırmaları Dergisi, 13(19), 281-310. DOI: 10.26466/opus.578149 